\title{
IDENTIFIKASI BAKTERI Escherichia coli PADA SAUS MAKANAN JAJANAN DI SEKITAR KAMPUS UNIVERSITAS MUHAMMADIYAH SURAKARTA
}

\author{
Devi Listiana Wardani ${ }^{1}$, Zulia Setiyaningrum ${ }^{2}$ \\ ${ }^{1,2}$ Program Studi Ilmu Gizi, Fakultas Ilmu Kesehatan, Universitas \\ Muhammadiyah Surakarta. \\ Jl. A. Yani Tromol Pos 1 Pabelan Kartasura, Surakarta, 57162, Jawa Tengah, \\ Indonesia \\ Email:1devi.listiana.wardani @gmail.com² zuliasetiyaningrum@ymail.com
}

Tanggal Submisi: 05 Desember 2019; Tanggal Penerimaan: 30 Desember 2019

\begin{abstract}
ABSTRAK
Makanan yang tidak aman akan menjadi penyebab terjadinya gangguan kesehatan pada masyarakat salah satunya oleh perilaku higiene sanitasi yang buruk. Penelitian ini bertujuan untuk mengetahui keberadaan bakteri Escherichia coli pada saus makanan yang dijual di sekitar kampus Universitas Muhammadiyah SurakartaPerilaku higiene sanitasi yang buruk dapat meningkatkan kemungkinan adanya pencemaran makanan dan menjadikan makanan tersebut menjadi tidak aman untuk dikonsumsi. Metode yang digunakan adalah deskriptif observasional. Sampel penelitian terdiri dari 21 saus cabai makanan yang dijajakan di sekitar kampus Universitas Muhammadiyah Surakarta. Identifikasi bakteri Escherichia coli dilakukan di laboratorium dengan metode kualitatif melalui tahap pengkayaan, isolasi dan identifikasi melalui uji biokimia fermentasi karbohidrat, Sulfide Indole Motility dan Simmons Citrate. Semua pengujian dilakukan sebanyak 2 kali. Hasil menunjukkan dari 21 sampel saus terdapat 7 sampel yang menunjukkan adanya bakteri Escherichia coli. Perilaku higinene sanitasi
\end{abstract}

Kata Kunci : Escherichia coli, Makanan Jajanan, Saus

ISSN 1979-7621 (Print). ISSN 2620-7761 (Online).

\begin{abstract}
ABSTRACK
Unsafe food increases the comunity health issue risk, one of them is behavior higiene poor sanitation. This study aims to discover the existence of Escherichia coli bacteria on food sauce on sold around Muhammadiyah University of Surakarta. The method used in this research is a descriptive observational study. Purposive random sampling is used to collect 21 chilli sauce samples. Identification of Escherichia coli is obtained through laboratoy qualitative method tests, which are: enrichment, isolation and biochemichal identification tests with carbohydrates fermentation, Sulfide Indole Motility and Simmons Citrate. All of
\end{abstract}


the tests stated above were done twice to ensure the results. The result of 21 sauce samples, there are 7 sauce samples contaminated Escherichia coli.

Keywords : Escherichia coli, Streed food, Sauce

\section{PENDAHULUAN}

Keamanan pangan menurut UU No. 18 tahun 2012 tentang pangan menyatakan bahwa makanan yang aman dikonsumsi adalah makanan yang terbebas dari cemaran fisik, biologis dan kimia. Keamanan pangan tersebut perlu diperhatikan agar dapat meningkatkan derajat kesehatan dan terhindar dari berbagai penyakit (Arisman, 2009).

Penyakit akibat kurang diperhatikannya keamanan pangan disebut dengan foodborne disease. Penyebab terjadinya foodborne disease adalah karena terkontaminasinya makanan oleh bakteri patogen (WHO, 2011). Salah satu jenis bakteri patogen penyebab foodborne disease adalah Escherichia coli yang berdampak pada penyakit diare (Winarno, 2008).

Prevalensi diare di Indonesia pada laporan Riskesdas (2013) tercatat sebanyak 3,5\% dan di Jawa Tengah tercatat sebanyak 3,3\%. Badan Pusat Statistik Provinsi Jawa Tengah (2016) juga masih tercatat adanya kasus diare sebanyak 4.849 kasus di Surakarta. Penyebab terjadinya diare dapat dipengaruhi oleh adanya kontaminasi bakteri Escherichia coli pada makanan yang dikonsumsi (Winarno, 2008).

Kontaminasi bakteri

Escherichia coli tersebut dikarenakan kurangnya higiene dan sanitasi pada makanan seperti pada pengolahan saus. Praktik pengolahan yang kurang tepat dapat dilihat dari higiene penjamah makanan, sanitasi peralatan dan bahan makanan yang digunakan, serta lokasi berjualan juga akan mempengaruhi kualitas saus tersebut (Gea, 2009).

Kualitas saus harus memenuhi persyaratan yang telah diatur dalam Peraturan Menteri Kesehatan Republik Indonesia Nomor 1096/Menkes/Per/VI/2011 yang yang mensyaratkan dalam makanan harus menunjukkan jumlah cemaran bakteri Escherichia coli yaitu nol (negatif), dengan kata lain dalam makanan tidak boleh terdapat bakteri Escherichia coli satu koloni pun. Beberapa penelitian ternyata masih menemukan adanya bakteri Escherichia coli pada saus seperti pada 12 sampel saus bakso tusuk di Manado, semuanya terbukti mengandung bakteri Escherichia coli (Mansudah, dkk., 2014). Penelitian Gracia, dkk (2002) menemukan 2 sampel (5\%) dari total 43 sampel saus pada makanan jajanan di Mexico yang mengandung bakteri Escherichia coli.

$\begin{array}{ccc}\text { Laporan } & \text { BPOM } & \text { (2016) } \\ \text { menyatakan } & \text { bahwa } & \text { sumber }\end{array}$
kontaminasi tertinggi kedua berasal dari makanan jajanan yaitu 12 kejadian $(20,34 \%)$ dan lokasi kejadian tertinggi kedua adalah lembaga pendidikan yaitu 18 kejadian (30\%). Universitas Muhammadiyah Surakarta merupakan lembaga pendidikan yang memiliki lebih dari 35.000 mahasiswa (UMS, 2017). Mahasiswa yang ada di Universitas ini berasal dari berbagai daerah dengan jumlah yang banyak, sehingga menyebabkan tingginya kebutuhan makanan dan tempat tinggal. Tingginya kebutuhan makanan ini berbanding lurus dengan banyaknya 
pedagang yang menjajakan makanan jajanan di sekitar kampus.

Berdasarkan latar belakang tersebut peneliti tertarik untuk melakukan penelitian yang berjudul "Identifikasi bakteri Escherichia coli pada saus makanan jajanan yang di jual di sekitar kampus Universitas Muhammadiyah Surakarta".

\section{METODE PENELITIAN}

Jenis penelitian ini adalah deskriptif observasional dengan jumlah sampel sebanyak 21 sampel saus cabai yang dipilih dengan metode purposive sampling dengan kriteria inklusi adalah saus cabai yang dijual di sekitar kampus 1, 2 dan 4 Universitas Muhammadiyah Surakarta, saus yang ditempatkan dengan menggunakan botol air mineral, botol plastik atau botol kaca dan saus yang diberi tambahan air sebagai pengencer.

Data identifikasi bakteri Escherichia coli diperoleh melalui pengujian di laboratorium mikrobiologi Balai Laboratorium Kesehatan Yogyakarta dengan menggunakan metode kualitatif. Pengujian dengan menggunakan metode kulatitatif meliputi tahap pengkayaan, tahap isolasi dan tahap identifikasi dengan menggunakan uji biokimia gula-gula, SIM (Sulfide Indol Motility) dan SC (Simmons Citrate) dengan kategori positif dan negatif. Kategori positif apabila dari hasil pengujian terbukti mengandung bakteri Escherichia coli sesuai dengan hasil pengujian di laboratorium menggunakan metode gula-gula, SIM dan SC. Kategori negatif apabila dari hasil pengujian tidak terbukti mengandung bakteri Escherichia coli sesuai dengan hasil pengujian di laboratorium menggunakan metode gula-gula, SIM dan SC.

Data perilaku higiene sanitasi dilakukan dengan cara observasi dan wawancara menggunakan kuesioner meliputi profil penjaja makanan, karakteristik saus, higiene penjamah makanan, sanitasi peralatan, sanitasi bahan makanan, penyimpanan dan sanitasi tempat berjualan.

Analisis data dilakukan dengan membandingkan hasil pengujian identifikasi bakteri Escherichia coli pada saus disajikan dalam bentuk distribusi tabel dan dideskripsikan sesuai dengan Peraturan Menteri Kesehatan RI Nomor 1096/Menkes/Per/VI/2011 tentang Higiene Sanitasi Jasa Boga yang mensyaratkan dalam makanan harus menunjukkan jumlah cemaran bakteri Escherichia coli yaitu nol (negatif), dengan kata lain dalam makanan tidak boleh terdapat bakteri Escherichia coli satu koloni pun. Data perilaku higiene sanitasi penjaja makanan disajikan dalam bentuk tabel distribusi dan dideskripsikan sesuai dengan kepustakaan yang relevan dan mengacu pada Peraturan Menteri Kesehatan Republik Indonesia yaitu Nomor 1096/Menkes/Per/VI/2011.

\section{HASIL DAN PEMBAHASAN}

\section{Profil Penjaja Makanan Jajanan}

Jumlah penjaja makanan dalam penelitian ini secara keseluruhan berjumlah 21 orang. Karakteristik penjaja makanan dilihat dari jenis kelamin, umur, tingkat pendidikan dan lama berjualan dalam sehari yang dapat dilihat pada Tabel 1. 
Tabel 1. Profil Penjaja Makanan

\begin{tabular}{lcc}
\hline \multirow{2}{*}{ Karakteristik } & \multicolumn{2}{c}{ Total } \\
\cline { 2 - 3 } & n & \% \\
\hline Jenis kelamin & & \\
Laki-laki & 18 & 85,7 \\
Perempuan & 3 & 14,3 \\
Umur & & \\
20-29 tahun & 7 & 33,3 \\
30-39 tahun & 9 & 42,9 \\
40-59 tahun & 5 & 23,8 \\
Tingkat pendidikan & & \\
Tamat SD & 4 & 19,0 \\
Tamat SMP & 8 & 38,1 \\
Tamat SMA & 9 & 42,9 \\
Lama berjualan/hari & & \\
1-6 jam & 0 & 0 \\
7-12 jam & 21 & 100 \\
\hline
\end{tabular}

Pada Tabel 1 diketahui bahwa jenis kelamin paling banyak dari 21 penjaja makanan yang dijadikan sampel adalah laki-laki yaitu sebanyak 18 orang $(85,7 \%)$. Rentang umur penjaja makanan paling banyak berada pada umur 30-39 tahun dengan umur terendah yaitu 21 tahun dan umur tertinggi yaitu 54 tahun.

Tingkat pendidikan penjaja makanan paling banyak adalah tamat SMA $(42,9 \%)$ dan tingkat pendidikan paling sedikit adalah tamat SD $(19,0 \%)$. Berdasarkan lama berjualan dalam sehari para penjaja makanan berjualan antara 7-12 jam, dengan waktu lama berjualan tersingkat adalah 7 jam dan terlama adalah 12 jam.

\section{Karakteristik Saus Makanan Jajanan}

Pada Tabel 2 di bawah ini menunjukkan karakteristik sampel saus yang beraneka ragam. Saus yang menjadi sampel, sebagian besar masih terlihat bahan penyusun lain seperti adanya bintik hitam dan adanya gumpalan. Selain itu, sebagian besar saus keadaannya cair. Saus yang dijual dari 21 pedagang hanya 1 pedagang yang murni membuat saus sendiri, sedangkan sisanya menggunakan saus yang dijual di pasaran kemudian meraciknya kembali dengan bahanbahan tambahan seperti bawang merah, bawang putih, cabai, garam dan gula.

Berdasarkan hasil wawancara mengenai saus yang digunakan oleh pedagang, didapatkan bahwa merk saus yang digunakan oleh pedagang makanan jajanan yang berada disekitar Universitas Muhammadiyah Surakarta diantaranya adalah ABC yang digunakan oleh 2 pedagang, Lombok Gandaria yang digunakan oleh 11 pedagang, Del Monte yang digunakan oleh 2 pedagang, Niki Harum digunakan oleh 4 pedagang dan Bagong yang digunakan oleh 1 pedagang. Beberapa alasan pemilihan merk tersebut adalah karena sudah terbiasa menggunakan merk tersebut, mudah ditemui, rasanya lebih enak dan harganya lebih murah.

\section{Identifikasi Bakteri Escherichia coli pada Saus Makanan Jajanan}

Dari pengujian laboratorium didapatkan hasil identifikasi bakteri Escherichia coli pada saus makanan jajanan dapat dilihat pada Tabel 3 . Pada Tabel 3 diketahui bahwa terdapat 7 sampel saus dari total 21 sampel yang teridentifikasi adanya bakteri Escherichia coli. Hal ini tidak sesuai dengan Peraturan Menteri Kesehatan RI Nomor 1096/Menkes/Per/VI/2011 yang mengharuskan bakteri Escherichia coli dalam makanan harus menunjukkan jumlah cemaran bakteri Escherichia coli harus nol (negatif). Apabila peraturan diatas tidak terpenuhi, maka makanan tersebut tidak memenuhi syarat kesehatan. 
D. L. Wardani \& Z. Setiyaningrum/Jurnal Kesehatan 12 (2) 2019, 91-101

Tabel 2. Karakteristik Saus

\begin{tabular}{|c|c|c|c|c|}
\hline \multirow{2}{*}{$\begin{array}{c}\text { Kode } \\
\text { Sampel }\end{array}$} & \multirow{2}{*}{ Jenis } & \multicolumn{3}{|c|}{ Karakteristik } \\
\hline & & Aroma & Penampilan* & Kekentalan \\
\hline $\mathrm{A}$ & Cilok & Aroma khas saus cabai & $\mathrm{N}$ & Cair \\
\hline B & Bakso goreng telur & Aroma khas saus cabai & $\mathrm{N}$ & Cair \\
\hline $\mathrm{C}$ & Cilok & Aroma khas saus cabai & $\mathrm{O}$ & Kental \\
\hline $\mathrm{D}$ & Bakso goreng telur & Aroma khas saus cabai & $\mathrm{N}$ & Kental \\
\hline $\mathrm{E}$ & Cilok & Aroma khas saus cabai & $\mathrm{O}$ & Cair \\
\hline $\mathrm{F}$ & Batagor & Aroma khas saus cabai & $\mathrm{O}$ & Kental \\
\hline $\mathrm{G}$ & Bakso kuah & Aroma khas saus cabai & $\mathrm{N}$ & Cair \\
\hline $\mathrm{H}$ & Sempolan & Aroma khas saus cabai & $\mathrm{N}$ & Cair \\
\hline I & Bakso goreng telur & Aroma khas saus cabai & $\mathrm{N}$ & Kental \\
\hline $\mathrm{J}$ & Cilok & Aroma khas saus cabai & $\mathrm{N}$ & Cair \\
\hline K & Cilok & Aroma khas saus cabai & $\mathrm{N}$ & Cair \\
\hline $\mathrm{L}$ & Bakso bakar & Aroma khas saus cabai & $\mathrm{N}$ & Cair \\
\hline M & Cilok & Aroma khas saus cabai & $\mathrm{N}$ & Cair \\
\hline $\mathrm{N}$ & Cireng, cilok, batagor & Aroma khas saus cabai & $\mathrm{N}$ & Kental \\
\hline $\mathrm{O}$ & Cilok & Aroma khas saus cabai & $\mathrm{N}$ & Kental \\
\hline$P$ & Bakso kuah & Aroma khas saus cabai & $\mathrm{O}$ & Kental \\
\hline $\mathrm{Q}$ & Bakso \& tahu goreng & Aroma khas saus cabai & $\mathrm{N}$ & Cair \\
\hline $\mathrm{R}^{2}$ & Hottang & Aroma khas saus cabai & $\mathrm{O}$ & Kental \\
\hline S & Cilok & Aroma khas saus cabai & $\mathrm{N}$ & Cair \\
\hline $\mathrm{T}$ & Cilok & Aroma khas saus cabai & $\mathrm{O}$ & Kental \\
\hline $\mathrm{U}$ & Bakso telur & Aroma khas saus cabai & $\mathrm{N}$ & Cair \\
\hline
\end{tabular}

*Keterangan : $\mathrm{N}=$ terlihat bahan penyusun lain

$\mathrm{O}=$ tidak terlihat bahan penyusun lain

Tabel 3. Hasil Identifikasi Bakteri Escherichia coli pada Saus

\begin{tabular}{|c|c|c|c|}
\hline & & & 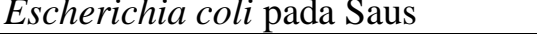 \\
\hline \multirow{2}{*}{$\begin{array}{c}\text { Kode } \\
\text { Sampel }\end{array}$} & Identifikasi & Kode & Identifikasi \\
\hline & $\begin{array}{c}\text { Escherichia } \\
\text { coli }\end{array}$ & & $\begin{array}{c}\text { Escherichia } \\
\text { coli }\end{array}$ \\
\hline $\mathrm{A}$ & -2 & $\mathrm{~L}$ & - \\
\hline B & + & $\mathrm{M}$ & - \\
\hline $\mathrm{C}$ & - & $\mathrm{N}$ & - \\
\hline $\mathrm{D}$ & + & $\mathrm{O}$ & - \\
\hline$E$ & + & $P$ & - \\
\hline $\mathrm{F}$ & - & Q & + \\
\hline $\mathrm{G}$ & - & $\mathrm{R}$ & - \\
\hline $\mathrm{H}$ & + & $S$ & - \\
\hline I & + & $\mathrm{T}$ & - \\
\hline $\mathrm{J}$ & - & $\mathrm{U}$ & - \\
\hline K & + & & \\
\hline
\end{tabular}

\section{Perilaku Higiene Sanitasi Penjaja Makanan}

Penjaja makanan yang dijadikan sampel penelitian diteliti mengenai perilaku higiene sanitasinya menggunakan kuesioner dengan hasil seperti pada Tabel 4.

Berdasarkan hasil penilaian terhadap higiene sanitasi penjaja makanan secara keseluruhan diketahui bahwa 12 penjaja makanan $(57,1 \%)$ sudah melakukan perilaku higiene sanitasi dengan baik sesuai dengan Peraturan Menteri Kesehatan Republik Indonesia Nomor 1096/Menkes/Per/VI/2011 tentang Higiene Sanitasi Jasaboga. Sebanyak 9 penjaja makanan lainnya $(42,9 \%)$ belum melakukan perilaku higiene sanitasi dengan baik.

Pada Tabel 4 di atas dapat diketahui bahwa masih ada penjaja makanan yang belum melakukan perilaku higiene sanitasi dengan baik. Berikut ini adalah uraian dari masing masing perilaku higiene sanitasi penjaja makanan: 
D. L. Wardani \& Z. Setiyaningrum/Jurnal Kesehatan 12 (2) 2019, 91-101

Tabel 4. Gambaran Higiene Sanitasi Penjaja Makanan

\begin{tabular}{cccccc}
\hline $\begin{array}{c}\text { Penjaja } \\
\text { Makanan }\end{array}$ & $\begin{array}{c}\text { Hasil } \\
\text { Penilaian }\end{array}$ & Kategori & $\begin{array}{c}\text { Penjaja } \\
\text { Makanan }\end{array}$ & $\begin{array}{c}\text { Hasil } \\
\text { Penilaian }\end{array}$ & Kategori \\
\hline A & $74,1 \%$ & Baik & L & $85,2 \%$ & Baik \\
B & $51,9 \%$ & Kurang Baik & M & $66,7 \%$ & Baik \\
C & $63 \%$ & Kurang Baik & N & $66,7 \%$ & Baik \\
D & $63 \%$ & Kurang Baik & O & $66,7 \%$ & Baik \\
E & $55,6 \%$ & Kurang Baik & P & $70,4 \%$ & Baik \\
F & $63 \%$ & Kurang Baik & Q & $63 \%$ & Kurang \\
G & $74,1 \%$ & Baik & $\mathrm{R}$ & $74,1 \%$ & Baik \\
H & $55,6 \%$ & Kurang Baik & S & $66,7 \%$ & Baik \\
I & $70,4 \%$ & Baik & T & $70,4 \%$ & Baik \\
J & $74,1 \%$ & Baik & U & $74,1 \%$ & Baik \\
K & $63 \%$ & Kurang Baik & & & \\
\hline
\end{tabular}

Berdasarkan hasil penilaian terhadap higiene sanitasi penjaja makanan secara keseluruhan diketahui bahwa 12 penjaja makanan $(57,1 \%)$ sudah melakukan perilaku higiene sanitasi dengan baik sesuai dengan Peraturan Menteri Kesehatan Republik Indonesia Nomor 1096/Menkes/Per/VI/2011 tentang Higiene Sanitasi Jasaboga. Sebanyak 9 penjaja makanan lainnya $(42,9 \%)$ belum melakukan perilaku higiene sanitasi dengan baik.

Pada Tabel 4 dapat diketahui bahwa masih ada penjaja makanan yang belum melakukan perilaku higiene sanitasi dengan baik. Berikut ini adalah uraian dari masing masing perilaku higiene sanitasi penjaja makanan:

\section{Higiene Penjamah Makanan}

Hasil observasi dan wawancara mengenai higiene penjamah makanan dapat dilihat pada Tabel 5. Beberapa kriteria higiene penjamah makanan yang belum dilakukan dengan baik adalah berkuku pendek dan bersih hanya dipenuhi sebesar $42,9 \%$. Hal ini bertentangan dengan Arisman (2009) yang menyatakan bahwa penjamah makanan harus memotong dan menjaga kebersihan kuku agar tidak berpotensi menempelnya kotoran dari kuku.

Berdasarkan hasil wawancara didapatkan hanya sebanyak 9 pedagang $(42,9 \%)$ yang mencuci tangan dengan menggunakan sabun dan air mengalir. Hal ini didukung dengan pernyataan Fathonah (2005) yang menyatakan bahwa mencuci tangan dengan sabun dan air mengalir merupakan cara yang dapat dilakukan untuk meningkatkan higiene penjamah makanan.

Pengeringan tangan dengan lap kain berualng kali dilakukan sebanyak 13 penjamah makanan $(61,9 \%)$. Hal ini bertentangan dengan pernyataan Sucipto (2016) yang mengatakan bahwa apabila tangan akan dikeringkan harus menggunakan lap yang diganti setiap hari agar selalu terjaga kebersihan dan kesterilannya agar tidak menjadi perantara bakteri patogen pada makanan (Fathonah, 2005).

Seluruh penjamah makanan (100\%) tidak menggunakan sarung tangan pada saat mengolah makanan. Penelitian Agustina, dkk (2009) 
menyatakan bahwa apabila penjamah makanan tidak menggunakan alas tangan saat mengolah makanan akan menyebabkan terjadinya pencemaran makanan karena mikroorganisme yang melekat pada tangan akan berpindah ke dalam makanan dan berkembangbiak dalam makanan.

\section{Sanitasi Peralatan}

Berdasarkan hasil observasi dan wawancara mengenai sanitasi peralatan dapat dilihat pada Tabel 6. Sebagian besar $(76,2 \%)$ wadah saus yang digunakan saat berjualan tidak ditutup. Hal ini bertentangan dengan penelitian Gea (2009) yang menyatakan bahwa wadah saus sebaiknya tertutup rapat karena wadah yang tidak tertutup akan meningkatkan terjadinya pencemaran makanan akibat pencemaran debu, kotoran yang dibawa oleh serangga seperti lalat yang dapat menjadi perantara kontaminan ke makanan akibat tidak tertutupnya wadah yang digunakan.

Tabel 5. Distribusi Frekuensi Responden Menurut Higiene Penjamah Makanan

\begin{tabular}{|c|c|c|c|c|c|}
\hline \multirow{2}{*}{ No } & \multirow{2}{*}{ Kriteria Higiene Penjamah Makanan } & \multicolumn{2}{|c|}{ Ya } & \multicolumn{2}{|c|}{ Tidak } \\
\hline & & $\mathbf{N}$ & $\%$ & $\mathbf{n}$ & $\%$ \\
\hline 1 & Tangan penjaja makanan berkuku pendek dan bersih & 9 & 42,9 & 12 & 57,1 \\
\hline 2 & Tidak merokok & 21 & 100 & 0 & 0 \\
\hline 3 & Tidak menggunakan perhiasan & 20 & 95,2 & 1 & 4,8 \\
\hline 4 & Pakaian yang digunakan bersih dan rapi & 21 & 100 & 0 & 0 \\
\hline 5 & $\begin{array}{l}\text { Penjamah makanan mencuci tangan dengan sabun dan air } \\
\text { sebelum mengolah saus dan makanan }\end{array}$ & 9 & 42,9 & 12 & 57,1 \\
\hline 6 & Penjamah mengeringkan tangan dengan menggunakan lap & 13 & 61,9 & 8 & 38,1 \\
\hline 7 & $\begin{array}{l}\text { Penjamah menggunakan sarung tangan dalam mengolah } \\
\text { makanan }\end{array}$ & 0 & 0 & 21 & 100 \\
\hline 8 & Penjamah makanan sehat & 21 & 100 & 0 & 0 \\
\hline
\end{tabular}

Tabel 6. Distribusi Frekuensi Responden Menurut Sanitasi Peralatan

\begin{tabular}{llcccc}
\hline \multirow{2}{*}{ No } & \multicolumn{1}{c}{ Kriteria Sanitasi Peralatan } & \multicolumn{2}{c}{ Ya } & \multicolumn{2}{c}{ Tidak } \\
\cline { 2 - 6 } & \multicolumn{1}{c}{ n } & \% & n & \% \\
\hline 1 & $\begin{array}{l}\text { Wadah saus yang digunakan dalam keadaan } \\
\text { tertutup }\end{array}$ & 5 & 23,8 & 16 & 76,2 \\
2 & $\quad$ Wadah saus yang digunakan tampak bersih & 21 & 100 & 0 & 0 \\
3 & $\begin{array}{l}\text { Wadah saus dan peralatan masak selalu dicuci } \\
\text { sebelum dan setelah digunakan }\end{array}$ & 21 & 100 & 0 & 0 \\
4 & $\begin{array}{l}\text { Wadah saus dan peralatan yang digunakan } \\
\text { selalu dicuci dengan sabun dan air mengalir }\end{array}$ & 14 & 66,7 & 7 & 33,3 \\
5 & $\begin{array}{l}\text { Penyimpanan wadah saus dan peralatan yang } \\
\text { sudah dicuci ditempatkan di tempat kering }\end{array}$ & 21 & 100 & 0 & 0 \\
6 & $\begin{array}{l}\text { Mengeringkan wadah saus dan peralatan } \\
\text { dengan menggunakan lap }\end{array}$ & 11 & 52,4 & 10 & 47,6 \\
\hline
\end{tabular}


Pencucian wadah dengan menggunakan sabun dan air mengalir hanya dilakukan oleh $33,3 \%$. Penelitian Huda dan Tuntun (2016) menyatakan bahwa wadah yang tidak dicuci dengan menggunakan air mengalir tersebut meninggalkan kuman pada air cucian dan dapat mencemari wadah saus yang telah dicuci.

Dari hasil wawancara sebanyak $52,4 \%$ penjaja makanan mengeringkan wadah saus dengan menggunakan lap yang telah dipakai berulang kali. Hal ini bertentangan dengan penelitian Kepriana (2016) yang menyatakan bahwa wadah yang sudah dicuci hendaknya dibiarkan kering sendiri, agar tidak terjadi kontaminasi silang dari lap yang mengandung bakteri ke wadah yang telah dicuci tersebut.

\section{Sanitasi Bahan Makanan Penyimpanan}

Hasil observasi dan wawancara mengenai sanitasi bahan makanan dan penyimpanan dapat dilihat pada Tabel 7. Penambahan air pada pengolahan saus dilakukan oleh seluruh penjaja makanan (100\%). Selain itu, penggunaan saus secara berulang juga menyebabkan adanya bakteri pada saus. Hal ini tidak sejalan dengan hasil wawancara pada penjaja makanan, karena masih ditemui sebesar $23,8 \%$ penjaja makanan yang menggunakan saus secara berulang dan menyimpan saus sisa pada suhu ruang.

Penelitian Aminah dan Hidayah (2006) mengatakan bahwa perlakuan yang tidak tepat pada saus yang dipanaskan atau didinginkan kembali untuk dijual keesokan harinya, akan menimbulkan bahaya mikobiologis jika penanganannya tidak tepat. Pemanasan kembali pada saus yang tepat adalah pada suhu di atas $60^{\circ} \mathrm{C}$ selama minimal 30 menit untuk mematikan bakteri Escherichia coli, sedangkan penyimpanan paling baik pada saus yang tidak habis adalah pada suhu beku (frezeer) (Radji, 2010).

\section{Sanitasi Tempat Berjualan}

Hasil observasi dan wawancara mengenai sanitasi bahan makanan dan penyimpanan dapat dilihat pada Tabel 8. Sanitasi tempat berjualan yang belum memenuhi persyaratan lokasi berjualan sejauh 100 meter dari selokan adalah sebesar 28,6\%. Sebanyak $19,0 \%$ penjaja makanan menyediakan tempat sampah tidak dalam keadaan tertutup. Hal ini tentunya juga dapat mempengaruhi adanya cemaran bakteri Escherichia coli pada saus yang disebabkan oleh selokan yang menjadi tempat tinggal lalat, sehingga apabila lalat tersebut hinggap pada makanan akan menyebabkan adanya kontaminasi akibat kotoran (feses) dari selokan atau dari lalat itu sendiri ke makanan tersebut (Hastutiek dan Fitri, 2007).

Berdasarkan hasil pengamatan pada penjaja makanan didapatkan bahwa hanya 4 penjaja makanan $(19,0 \%)$ yang menyediakan tempat untuk mencuci tangan, namun selama pengamatan peneliti tidak melihat adanya penjaja makanan yang mencuci kembali tangan mereka setelah memegang uang atau anggota tubuh lainnya. Seharusnya, tersedianya air untuk cuci tangan tersebut digunakan untuk menjaga kebersihan penjamah makanan dari bakteri dan kotoran dapat berpindah melalui tangan yang kotor ke makanan. Oleh sebab itu, kebersihan tangan perlu dijaga dengan cara mencuci tangan dengan sabun 
sebagai pembersih dan penggunaan air yang mungkin terdapat mengalir akan menghilangkan kotoran mikroorganisme (Fathonah, 2005).

Tabel 7. Distribusi Frekuensi Responden Menurut Sanitasi Bahan Makanan

\begin{tabular}{llcccc}
\hline \multirow{2}{*}{ No } & \multicolumn{1}{c}{ Kriteria Sanitasi Bahan } & \multicolumn{2}{c}{ Ya } & \multicolumn{2}{c}{ Tidak } \\
\cline { 3 - 6 } & \multicolumn{1}{c}{$\mathbf{N}$} & $\mathbf{\%}$ & $\mathbf{n}$ & \% \\
\hline 1 & $\begin{array}{l}\text { Mencuci bahan-bahan untuk membuat saus sebelum diolah } \\
2\end{array}$ & 21 & 100 & 0 & 0 \\
& $\begin{array}{l}\text { Mencuci bahan-bahan untuk membuat saus dengan air } \\
\text { mengalir }\end{array}$ & 13 & 61,9 & 8 & 38,1 \\
3 & $\begin{array}{l}\text { Memisahkan bahan yang masih segar dan busuk untuk } \\
\text { membuat saus }\end{array}$ & 21 & 100 & 0 & 0 \\
4 & Menambahkan air pada saus & 21 & 100 & 0 & 0 \\
5 & Memasak saus hingga mendidih & 21 & 100 & 0 & 0 \\
6 & Membuang sisa saus yang tidak habis & 16 & 76,2 & 5 & 23,8 \\
\hline
\end{tabular}

Tabel 8. Distribusi Frekuensi Responden Menurut Sanitasi Tempat Berjualan

\begin{tabular}{llcccc}
\hline \multirow{2}{*}{ No } & \multicolumn{1}{c}{ Kriteria Sanitasi Tempat Berjualan } & \multicolumn{2}{c}{ Ya } & \multicolumn{2}{c}{ Tidak } \\
\cline { 3 - 6 } & & $\mathbf{N}$ & $\mathbf{\%}$ & $\mathbf{n}$ & \% \\
\hline 1 & Lokasi berjualan sejauh 100 m dari selokan & 15 & 71,4 & 6 & 28,6 \\
2 & Lokasi berjualan sejauh 100 m dari pembuangan limbah & 21 & 100 & 0 & 0 \\
3 & Lokasi berjualan sejauh 100 m dari tempat sampah umum & 21 & 100 & 0 & 0 \\
4 & Gerobak yang digunakan bersih & 19 & 90,5 & 2 & 9,5 \\
5 & Tersedianya air cuci tangan di lokasi berjualan & 4 & 19,0 & 17 & 81,0 \\
6 & Tersedianya tempat sampah di lokasi berjualan & 4 & 19,0 & 17 & 81,0 \\
7 & Tersedianya tempat sampah yang tertutup di lokasi berjualan & 0 & 0 & 4 & 100 \\
\hline
\end{tabular}

\section{KESIMPULAN}

Terdapat 7 sampel saus yang teridentifikasi adanya bakteri Escherichia coli. Sebanyak 12 penjaja makanan telah melakukan perilaku higiene sanitasi dengan baik dan 9 penjaja makanan belum melakukan perilaku higiene sanitasi dengan baik. Beberapa perilaku higiene sanitasi yang belum dilakukan dengan baik antara lain adalah higiene penjamah makanan (tangan penjaja makanan yang tidak berkuku pendek dan bersih, tidak mencuci tangan dengan sabun dan air mengalir sebelum mengolah saus dan makanan, tidak menggunakan sarung tangan saat mengolah makanan dan mengeringkan tangan dengan menggunakan lap yang telah digunakan berulang kali). Sanitasi peralatan (wadah saus yang digunakan tidak dalam keadaan tertutup dan mengeringkan wadah saus serta peralatan dengan lap yang telah digunakan secara berulang kali). Sanitasi bahan makanan dan penyimpanan (mencuci bahan-bahan dalam pembuatan saus dengan air yang tidak mengalir dan menambahkan air pada saus yang digunakan). Sanitasi lokasi berjualan (tidak menyediakan tempat sampah yang tertutup dan tidak tersedianya air tempat cuci tangan di lokasi berjualan).

\section{UCAPAN TERIMAKASIH}

Terima kasih kepada penjaja makanan di daerah kampus 1, 2 dan 4 Universitas Muhammadiyah Surakarta yang telah bersedia untuk menjadi 
D. L. Wardani \& Z. Setiyaningrum/Jurnal Kesehatan 12 (2) 2019, 91-101

responden penelitian dan terimakasih kepada laboran di laboratorium mikrobiologi Balai Laboratorium

Kesehatan Yogyakarta yang telah membantu penelitian sehingga berlangsung dengan lancar.

\section{DAFTAR PUSTAKA}

Agustina, F., Pambayun, R., Febry, F. (2009). Higiene dan Sanitasi Pada Pedagang Makanan Jajanan Tradisional di Lingkungan Sekolah Dasar di Kelurahan Demang Lebar Daun Palembang. Naskah Publikasi. Universitas Sriwijaya.

Aminah, S dan Hidayah, N. (2006). Pengetahuan Keamanan Pangan Penjual Makanan Jajanan Di Lingkungan Sekolah Kelurahan Wonogiri Kecamatan Semarang Selatan Kota Semarang. Jurnal Litbang Universitas Muhammadiyah Semarang. 4 (3): 18-25.

Arisman. (2009). Buku Ajar Ilmu Gizi Keracunan Makanan. Jakarta: Penerbit Buku Kedokteran EGC.

Badan Pengawas Obat dan Makanan (BPOM). (2016). Laporan Tahunan Badan POM RI Tahun 2015. Jakarta: Badan Pengawas Obat dan Makanan.

Badan Pusat Statistik. (2016). Provinsi Jawa Tengah dalam Angka. Jawa Tengah: Badan Pusat Statistik.

Fathonah, S. (2005). Higiene dan Sanitasi Makanan. Semarang: Unnes Press.

Garcia, T.E., Cerna, J.F., Thompson, M.R, Lopez-Saucendo, C. (2002). Faecal Contamination and Enterotoxigenic Escherichia Coli in Street-vended Chili Sauce in Mexico and Its Public Health Relevance. Epidemiology and Infection. 129(1): 223-226.

Gea, S.I. (2009). Hygiene Sanitasi dan Analisis Cemaran Mikroba yang Terdapat Pada Saus Tomat dan Saus Cabai Isi Ulang yang Digunakan Di Lingkungan Universitas Sumatera Utara Tahun 2009. Skripsi. Universitas Sumatera Utara.

Hastutiek, P dan Fitri, L.E. (2007). Potensi Musca domestica Linn. sebagai Vektor Beberapa Penyakit. Jurnal Kedokteran Brawijaya.13 (3): 125-136.

Huda, M dan Tuntun, M. (2015). Faktor-Faktor Yang Berhubungan Dengan Jumlah Mikroba Pada Kecap Manis Isi Ulang Yang Digunakan Penjual Bakso Di Kecamatan Way Halim Kota Bandar Lampung. Jurnal Analis Kesehatan. 4(1): 355-365.

Kementerian Kesehatan (Kemenkes). (2011). Peraturan Menteri Kesehatan Republik Indonesia Nomor : 1096/Menkes/Per/VI/2011 tentang Higiene Sanitasi Jasa Boga. Jakarta: Menteri Kesehatan Republik Indonesia.

Kepriana, V. (2016). Hubungan Antara Higiene Dan Sanitasi Dengan Jumlah Angka Kuman Pada Sambal Di Warung Tenda Kota Pontianak Tahun 2016. Skripsi. Universitas Muhammadiyah Pontianak.

Mansaudah, K.L., Fatimah, Kojong, N. (2014). Analisis Cemaran Bakteri Coliform pada Saus Tomat Jajanan Bakso Tusuk yang Beredar di Manado. Jurnal Ilmiah Farmasi. 3(2): 37-44.

Radji, M. (2010). Buku Ajar Mikrobiologi : Panduan Mahasiswa Farmasi \& Kedokteran. Jakarta: Penerbit Buku Kedokteran EGC. 
D. L. Wardani \& Z. Setiyaningrum/Jurnal Kesehatan 12 (2) 2019, 91-101

Riset Kesehatan Dasar (Riskesdas). (2013). Laporan Hasil Riset Kesehatan Dasar 2013. Jakarta: Badan Penelitian dan Pengembangan.

Sucipto, C.D. (2016). Keamanan Pangan Untuk Kesehatan Manusia. Yogyakarta: Gosyen Publishing.

Universitas Muhammadiyah Surakarta. (2017). Mahasiswa. Diakses : 23 November 2017. Http://www.ums.ac.id/id/mahasiswa

Winarno, F.G. (2008). Kimia Pangan Dan Gizi Edisi Terbaru Cetakan 1. Bogor: M-Brio Press.

World Health Organization (WHO). (2011). Initiative to estimate the Global Burden of Foodborne Diseases: Information and publications. Diakses : 24 Mei

2017. Http://www.who.int/foodsafety/foodborne_disease/ferg/en/index 7.html. 